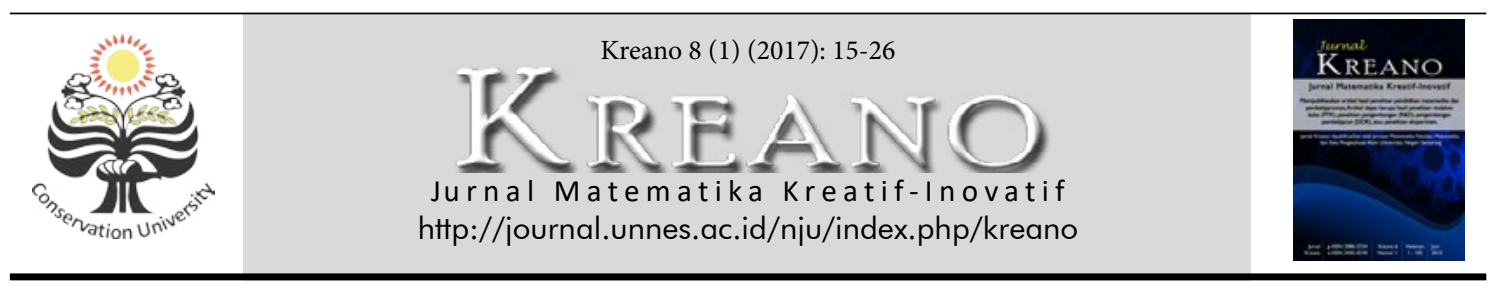

\title{
Pengembangan Perangkat Pembelajaran Telaah Kurikulum Matematika 1 Mengintegrasikan Kreativitas dan Karakter Cerdas melalui Pembelajaran Kooperatif Berbasis Asesmen Proyek
}

\author{
M. Asikin' ${ }^{1}$ Rochmad ${ }^{2}$, Ary Woro Kurniasih ${ }^{3}$ \\ 1,2,3Universitas Negeri Semarang, Indonesia \\ Email: asikin.mat@mail.unnes.ac.id'
}

DOI: http://dx.doi.org/10.15294/kreano.v8i2.4983

Received : February 2016; Accepted: May 2016; Published: June 2017

\begin{abstract}
Abstrak
Tujuan penelitian ini adalah mengetahui bagaimana proses dan hasil pengembangan perangkat pembelajaran telaah kurikulum matematika 1 yang mengintegrasikan kreativitas dan karakter cerdas melalui pembelajaran kooperatif berbasis asesmen proyek. Penelitian ini merupakan penelitian pengembangan. Produk yang dikembangkan dan diuji cobakan dalam penelitian ini adalah perangkat pembelajaran Telaah kurikulum matematika 1 mengintegrasikan kreativitas dan karakter cerdas melalui pembelajaran kooperatif berbasis asesmen proyek. Adapun model pengembangan perangkat yang akan digunakan pada penelitian ini adalah model yang dikembangkan oleh Plomp (1997). Perangkat yang dikembangkan kemudian divalidasi ahli dan diujicobakan. Model pembelajaran yang digunakan adalah pembelajaran kooperatif. Subjek penelitian ini mahasiswa Telaah Kurikulum Matematika 1 sebanyak 45 orang. Hasil penelitian menghasilkan perangkat yang valid. Implementasi pengembangan Perangkat Pembelajaran Telaah Kurikulum Matematika 1 Mengintegrasikan Kreativitas dan Karakter Cerdas Melalui Pembelajaran Kooperatif Berbasis Asesmen Proyek menunjukkan praktis dan efektif.
\end{abstract}

\begin{abstract}
The purpose of this research is to know how the process and result of development of learning tool of mathematics curriculum 1 that integrates creativity and intelligent character through cooperative learning based on project assessment. This research is a development research. The product developed and tested in this research is the learning tool Mathematics curriculum 1 integrates creativity and intelligent character through cooperative learning based on project assessment. The device development model that will be used in this research is the model developed by Plomp (1997). The developed tools were then validated and tested. The learning model used is cooperative learning. The subjects of this study are students of Mathematics Curriculum Curriculum 1 of 45 people. The results of the study produced a valid device. Implementation of Learning Mathematics Curriculum Development Toolkit I Integrating Creativity and Smart Character Through Cooperative Learning Based Project Assessment demonstrates the practical and effective.
\end{abstract}

Keywords: device development; creativity; Smart character; Project assessment; Cooperative learning.

\section{PENDAHULUAN}

Mata kuliah Telaah Kurikulum Matematika 1 merupakan salah satu mata kuliah mata semester genap 2014/2015 yang mengkaji tentang perkembangan Kurikulum di Indonesia, penyusunan dan pengembangan perangkat pembelajaran (penggalan silabus, penggalan RPP, penggalan bahan ajar, penggalan penilai- an) matematika kelas VII dan VIII, dan mempraktekkan pembelajaran matematika kelas VII dan VIII. Berdasarkan pengalaman pengampu mata kuliah ini di tahun-tahun sebelumnya (2011-2014), mahasiswa yang mengambil mata kuliah telaah kurikulum Matematika 1 menunjukkan (1) kurang kreatif dalam menyusun penggalan pembelajaran, (2) kurang 
kreatif memunculkan tema-tema baru dalam mempraktekkan pembelajaran, (3) kurang kreatif juga dalam menyusun soal-soal matematika karena soal yang dibuat umumnya hanya soal penerapan konsep sesuai dengan apa yang sudah ada di buku-buku pelajaran matematika yang dikeluarkan pemerintah maupun penerbit-penerbit. Selain itu, untuk karakter konservasi Unnes juga belum pernah diperhatikan dengan seksama oleh pengampu sebagai salah satu aspek penilaian dalam pembelajaran mata kuliah Telaah Kurikulum Matematika 1. Pada penelitian ini akan diperhatikan hanya satu karakter konservasi unnes yaitu karakter cerdas.

Unnes sebagai salah satu LPTK di Indonesia juga mempunyai nilai-nilai karakter konservasi sebagai ciri khas dan keunggulan keluaran Unnes yaitu religius, jujur, cerdas, adil, tanggung jawab, peduli, toleran, demokratis, cinta tanah air, tangguh, dan santun. Pembelajaran setiap mata kuliah di Unnes mengimplementasikan nilai-nilai karakter.

Pembelajaran Telaah Kurikulum Matematika 1 selama ini telah mulai dengan kegiatan mengaktifkan mahasiswa mengembangkan perangkat pembelajaran matematika SMP kelas VII dan VIII. Perangkat pembelajaran yang dikembangkan pengampupun (silabus, SAP, kontrak perkuliahan) telah mengakomodasi kebutuhan tersebut. Namun berdasarkan fakta bahwa kreativitas mahasiswa yang mengambil mata kuliah ini masih kurang dan belum diperhatikannya bentuk penilaian karakter cerdas maka perlulah untuk dikembangkan perangkat pembelajaran Telaah kurikulum matematika 1 yang mengintegrasikan kreativitas dan karakter cerdas mahasiswa.

Li (2013) menyatakan bahwa dengan pembelajaran kooperatif, peserta didik dapat memaksimalkan belajar dirinya dan teman ketika mereka bekerja bersama-sama. Menurut Slavin (dalam Li, 2013), elemen penting pembelajaran kooperatif adalam kerja kelompok dan tujuan tim itu sendiri. Banyak penelitian yang menunjukkan bahwa pembelajaran kooperatif merupakan metode belajar yang berhasil diantaranya Acar \& Tarhan, 2008; Doymus, 2008; Kirschner, Strijbos, Kreijns, \& Beers 2004b; Kramarski \& Mizrachi, 2006;
Mevarech \& Fridkin, 2006; NCTM, 2008;Tarım, 2009; Tarım, 2003; Tarım \& Artut, 2004; Webb et al.,2009 (Jbeili, 2012).

Proyek merupakan rencana pekerjaan dengan sasaran khusus dan saat penyelesaian yang tegas (Depdiknas dalam Masrukan, 2014). Asesmen proyek merupakan penilaian terhadap suatu tugas yang harus diselesaikan dalam waktu tertentu. Asesmen proyek dapat memfokuskan pada proses atau produk. Asesmen proyek yang berfokus pada proses digunakan sebagai sarana mengembangkan dan memonitor keterampilan peserta didik dalam merencanakan, menyelidiki, dan menganalisis proyek. Asesmen proyek yang berfokus pada hasil digunakan sebagai sarana penilaian kemampuan-kemampuan peserta didik mengkomunikasikan sesuatu melalui bentuk laporan tertulis.

Menurut Plomp (1997) ada lima tahapan yang harus dilalui dalam mengembangkan model pembelajaran. Model umum untuk memecahkan masalah bidang pendidikan yang dikemukakan Plomp (1997:5), yang dalam tulisan ini disebut model Plomp, digambarkan sebagai berikut.

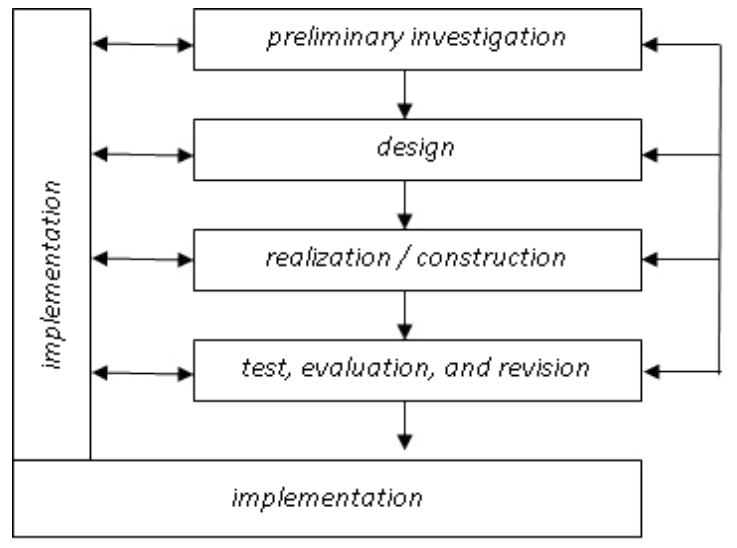

Gambar 1. Model Umum Pengembangan Bidang Pendidikan

(Sumber: Plomp, 1997:5)

Keterangan:

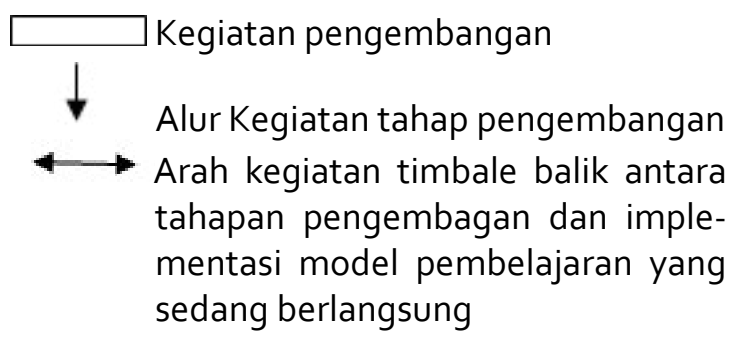


Siklus kegiatan pengembangan

Model Plomp terdiri dari fase investigasi awal (prelimenary investigation), fase desain (design), fase realisasi/konstruksi (realization/ construction), dan fase tes, evaluasi dan revisi (test, evaluation and revision), dan implementasi (implementation). Sedangkan untuk perangkat pembelajaran, hanya dilakukan sampai pada tahap keempat.

Tahap 1. Investigasi Awal (Preliminary Investigation). Inti dari tahapan ini adalah menganalisis kebutuhan atau masalah yang mencakup: (1) Identifikasi informasi, (2) Analisis informasi, (3) Definisi (batasan) masalah, dan (4) Rencana kegiatan lanjutan.

Tahap 2. Tahap Desain (Design). Tahap desain ini bertujuan merancang penyelesaian masalah yang telah diidentifikasi pada Tahap 1. Rancangan ini mencakup suatu proses yang sistematik, yaitu masalah lengkap dibagi menjadi sub-sub masalah dengan rancangan penyelesian masing-masing sub masalah. Selanjutnya penyelesaian masing-masing sub masalah dirangkum kembali menjadi suatu struktur pemecahan masalah secara lengkap. Tahap 3. Realisasi/Konstruksi (Realization/ Construction). Pada tahap ini dibuat prototipe dari penyelesaian masalah yang telah dirancang pada Tahap 2. Pada kaitannya dengan masalah pendidikan, Tahap 2 dan Tahap 3 ini biasanya disebut Tahap Produksi. Tahap 4. Tes Pengujian, Evaluasi, dan Revisi (Test, Evaluation, and Revision).Tes Pengujian dilakukan untuk mempertimbangkan kualitas rancangan penyelesaian yang telah dikembangkan. Berdasarkan hasil pertimbangan yang matang dibuat suatu keputusan untuk menentukan langkah selanjutnya. Evaluasi yang dilakukan mencakup proses menghimpun, memproses, dan menganalisis secara sistematis. Tujuan evaluasi adalah untuk menilai kualitas rancangan penyelesaian masalah. Langkah berikutnya adalah mengadakan revisi apabila pada kegiatan evaluasi masih ditemukan kekurangan yang terdapat pada rancangan penyelesaian masalah yang telah dibuat. Kegiatan evaluasi dan kegiatan revisi memungkinkan terjadi siklus. Siklus ini akan selesai apabila sudah mendapatkan penyelesaian masalah yang diharapkan.

Pada penelitian pengembangan, hasil pengembangan dapat berupa prototipe model atau perangkat pembelajaran. Untuk memperoleh hasil pengembangan yang berkualitas diperlukan penilaian. Untuk menentukan kualitas hasil pengembangan model dan perangkat pembelajaran diperlukan tiga kriteria: kevalidan, kepraktisan, dan keefektifan.

Kreativitas adalah sebuah proses pembuatan produk-produk dengan mentransformasi produk-produk yang sudah ada. Produk-produk tersebut secara nyata maupun tidak kasat mata harus unik (baru) hanya bagi penciptanya, dan harus memenuhi kriteria tujuan dan nilai yang ditentukan oleh penciptanya. Proses dalam pembuatan produk ini masih menfokuskan pada produk kreatif, tidak menjelaskan secara rinci langkahlangkah proses mental yang terjadi. Isaksen dan Trefingger (dalam Isaksen dan Murdock, 1988) mendefinisikan kreativitas merupakan sebuah pembuatan dan pengkomunikasian hubungan-hubungan baru yang bermakna untuk membantu (a) memikirkan berbagai kemungkinan; (b) memikirkan dan mengalami dalam berbagai cara serta menggunakan pandangan-pandangan baru; (c) memikirkan kemungkinan-kemungkinan baru dan tidak biasa; (d) membimbing seseorang dalam pembuatan dan pemilihan alternatif-alternatif. Definisi ini lebih menekankan pada proses untuk menjadikan seseorang kreatif.

Kurikulum Unnes telah ditetapkan berdasarkan Peraturan Rektor Universitas Negeri Semarang Nomor 25/2012 tentang Kurikulum Program Sarjana dan Diploma Unnes. Nilainilai karakter konservasi sebagai ciri khas dan keunggulan keluaran Unnes adalah religius, jujur, cerdas, adil, tanggung jawab, peduli, toleran, demokratis, cinta tanah air, tangguh, dan santun (Unnes, 2012). Cerdas adalah sikap dan perilaku seseorang yang menggambarkan kemampuan berpikir dan berperilaku yang logis dan objektif sesuai dengan nilainilai dan norma-norma kebenaran serta harkat dan martabat manusia. Beberapa kriteria normatif cerdas, di antaranya: (1) berpikir logis sesuai dengan konsep ilmu pengetahuan, teknologi, seni, dan/atau olahraga; (2) mene- 
mukan kebenaran secara logis dan metodologis; (3) memecahkan masalah secara tepat dan akurat berdasarkan data empiris; (4) kreatif dalam mengembangkan model atau caracara yang baru; (5) menemukan solusi secara cepat berdasarkan pemikiran yang logis (Unnes, 2012). Implementasi Kurikulum 2012 tepat dengan penggunaan model pembelajaran yang efektif. Pembelajaran kooperatif sangat direkomendasikan digunakan untuk meningkatkan kinerja kognitif, hubungan sosial, dan pemahaman matematis (Tarım, 2009; Tarım, 2003; Tarım \& Artut, 2004 dalam Jbeili, 2012).

Bentuk asesmen yang direkomendasikan dalam belajar matematika adalah investigasi matematika, proyek, penugasan, tes dan ujian, kinerja di kelas, dan tugas rumah (PR). Selain itu ada bentuk asesmen lain yang berguna dalam asesmen proses belajar yaitu presentasi, simulasi, pengamatan, interview, pertanyaan terstruktur, kuisioner. Proyek matematika merupakan asesmen holistic kemampuan pembelajar untuk menerapkan pengetahuan, keterampilan dan nilai dalam konteks proyek. Asesmen terhadap proyek matematika dapat dilakukan dalam bentuk asesmen tiap proses proyek tersebut maupun dalam bentuk keseluruhan proyek yang dihasilkan. Proyek matematika harus berorientasi pada masalah, atau memberikan kesempatan untuk menganalisis suatu fenomena matematika. Proyek matematika dapat disusun dalam bentuk yang beragam. Aktivitas yang dapat dipandang sebagai bagain dari proyek matematika adalah penelitian, ekskursi, kunjungan, demonstrasi, ekshibisi. (Department Education Republic of South Africa, Tanpa tahun).

Berdasarkan uraian di atas, maka kajian mengenai pengembangan perangkat pembelajaran telaah kurikulum matematika 1 yang mengintegrasikan kreativitas dan karakter cerdas melalui pembelajaran kooperatif berbasis asesmen proyek, perlu untuk dilakukan. Permasalahan dalam penelitian ini adalah: Bagaimana proses dan hasil pengembangan Perangkat Pembelajaran Telaah Kurikulum Matematika 1 Mengintegrasikan Kreativitas Dan Karakter Cerdas Melalui Pembelajaran Koopera- tif Berbasis Asesmen Proyek?

\section{METODE}

Penelitian ini merupakan penelitian pengembangan. Produk yang dikembangkan dan diuji cobakan dalam penelitian ini adalah perangkat pembelajaran Telaah kurikulum matematika 1 mengintegrasikan kreativitas dan karakter cerdas melalui pembelajaran kooperatif berbasis asesmen proyek. Pengembangan produk ini mengacu pada model pengembangan pendidikan umum dari Plomp. Kegiatankegiatan yang dilakukan dalam mengembangkan produk ini adalah: 1) Tahap Investigasi Awal, 2) Tahap perancangan/ desain, 3) Tahap Realisasi / Konstruksi, 4) Tahap Pengujian, Evaluasi, dan Revisi . Untuk melihat kevalidan perangkat pembelajaran digunakan validasi ahli dengan data pernyataan tentang kevalidan perangkat pembelajaran yang dikembangkan. Sumber data adalah dua orang ahli yang kompeten dalam bidang pengembangan perangkat pembelajaran, yaitu Bambang Eko Susilo, S.Pd, M.Pd dan Hery Sutarto, S.Pd, M.Pd. Untuk melihat kepraktisan digunakan Lembar pengamatan Keterlaksanaan Pembelajaran dan Lembar Angket Respon Mahasiswa. Untuk melihat keefektifan berdasarkan dua hal yaitu hasil belajar (tes mengukur kreativitas mahasiswa) dan aktivitas mahasiswa (menggunakan lembar pengamatan kreativitas, lembar pengamatan pelaksanaan peer teaching, angket penilaian diri karakter cerdas, angket penilaian kreativitas)

Sumber data pada penelitian ini adalah mahasiswa semester 2 program studi pendidikan matematika jurusan Matematika FMIPA Unnes tahun akademik 2014/2015. Instrumen penelitiannya adalah Lembar Validasi perangkat pembelajaran, Lembar pengamatan Keterlaksanaan Pembelajaran dalam mengelola pembelajaran dengan pembelajaran kooperatif dengan kategori minimal baik, Lembar Angket Respon Mahasiswa dengan kategori 
minimal baik, lembar pengamatan kreativitas mahasiswa melaksanakan asesmen proyek, lembar pengamatan pelaksanaan peer teaching mahasiswa yang menunjukkan kreativitas, Angket penilaian kreativitas mahasiswa, tes siklus 1, tes siklus 2, Angket penilaian diri karakter cerdas.

\section{HASIL DAN PEMBAHASAN}

\section{Hasil}

Hasil Fase Investigasi Awal yaitu identifikasi dan kajian terhadap terhadap (1) Kurikulum 2013 mata pelajaran Matematika SMP, (2) Kompetensi dasar matematika kelas VII dan VIII, (3) kreativitas, karakter cerdas, asesmen proyek, dan pembelajaran kooperatif. Kurikulum yang digunakan pada penelitian ini adalah Kurikulum 2013. Kurikulum 2013 ini dipertegas dengan Peraturan Menteri Pendidikan dan Kebudayaan Republik Indonesia Nomor 58 tahun 2014 tentang Kurikulum 2013 sekolah menengah pertama/Madrasah tsanawiyah (Depdikbud, 2014). Menurut Permendikbud ini, Kurikulum 2013 Sekolah Menengah Pertama/Madrasah Tsanawiyah kerangka Dasar Kurikulum; Struktur Kurikulum; Silabus; dan Pedoman Mata Pelajaran.

Kreativitas dalam penelitian ini memuat 3 indikator yaitu Merangsang keingintahuan yang menghasilkan cara atau hasil baru yang telah dimiliki (K1), Mengemukakan pikiran atau gagasan yang menghasilkan cara atau hasil baru yang telah dimiliki (K2), Melakukan tindakan yang menghasilkan cara atau hasil baru yang telah dimiliki $\left(\mathrm{K}_{3}\right)$. Untuk melihat keativitas, digunakan lembar pengamatan kreativitas mahasiswa secara berkelompok (melaksanakan asesmen proyek dan diisi oleh dosen), dan Angket penilaian kreativitas kelompok (diisi oleh kelompok yang bersangku$\tan )$.

Karakter cerdas dalam penelitian ini meliputi 5 indikator yaitu (1) berpikir logis sesuai dengan konsep ilmu pengetahuan, teknologi, seni, dan/atau olahraga, (2) menemukan kebenaran secara logis dan metodologis, (3) memecahkan masalah secara tepat dan akurat berdasarkan data empiris, (4) kreatif dalam mengembangkan model atau cara-cara yang baru, (5) menemukan solusi secara cepat berdasarkan pemikiran yang logis. Karakter cerdas dinilai dengan menggunakan lembar penilaian diri (penilaian diri sendiri setiap mahasiswa).

Perkuliahan Telaah Kurikulum Matematika 1 dilaksanakan selama 16 pertemuan (termasuk UTS dan UAS) dengan pembelajaran kooperatif . Asesmen proyek dalam penelitian ini berbentuk penugasan kepada setiap kelompok mahasiswa (4 orang) yaitu (1) menggali informasi tentang kuurikulum-kurikulum yang pernah ada di Indonesia, (2) mengembangkan aktivitas pendekatan ilmiah, (3) mengembangkan penggalan silabus matematika kelas VII dan VIII materi matematika tertentu, (4) mengembangkan skenario pembelajaran yang menekankan pada pendekatan ilmiah sesuai materi matematika yang dipilih, (5) mengembangkan bahan ajar, (6) mengembangkan penilaian. Setelah mahasiswa mampu mengembangkan perangkat pembelajaran matematika kelas VII dan VIII tersebut, di pertemuan perkuliahan ke 10 sampai dengan 13 setiap kelompok mempraktekkan pembelajaran matematika dengan fokus adalaha pendekatan ilmiah. Sedangkan di pertemuan 14 dan 15, mahasiswa dipeerkenalkan dengan soal matematika open-ended dan menyelesaikan soal matematika yang bersifat open ended.

Hasil Fase Desain yaitu menentukan perangkat yang dirancang berupa (1) silabus, (2) satuan acara perkuliahan, (3) angket penilaian kreativitas, (4) angket karakter cerdas, (5) asesmen proyek, (6) kontrak perkuliahan, (7) instrumen penilaian pelaksanaan pembelajaran peer teaching, (8) lembar pengamatan kreativitas mahasiswa, (9) Tes matematika yang sesuai dengan dengan pembelajaran kooperatif dengan integrasi kreativitas dan karakter cerdas pada telaah kurikulum matematika 1 yang mengintegrasikan kreativitas dan karakter cerdas me- 
Tabel 1. Hasil validasi perangkat pembelajaran

\begin{tabular}{ccccccc}
\hline silabus & SAP & $\begin{array}{c}\text { kontrak } \\
\text { perkuliahan }\end{array}$ & $\begin{array}{c}\text { angket pe- } \\
\text { nilaian diri } \\
\text { karakter cerdas }\end{array}$ & $\begin{array}{c}\text { angket pe- } \\
\text { nilaian kreati- } \\
\text { vitas maha- } \\
\text { siswa }\end{array}$ & $\begin{array}{c}\text { instrumen pe- } \\
\text { nilaian pelaksa- } \\
\text { naan peer teaching }\end{array}$ \\
\hline $\begin{array}{c}\text { Valida- } \\
\text { tor 1 }\end{array}$ & $86,36 \%$ & $88,63 \%$ & $93,18 \%$ & $87,5 \%$ & $88,63 \%$ & $88,33 \%$ \\
\hline $\begin{array}{c}\text { Valida- } \\
\text { tor 2 }\end{array}$ & $88,63 \%$ & $90,9 \%$ & $86,36 \%$ & $91,67 \%$ & $86,36 \%$ & (baik) \\
(baik) & (baik) & (baik) & (baik) & (baik) & (baik) & $86,67 \%$ \\
\hline
\end{tabular}

lalui pembelajaran kooperatif berbasis asesmen proyek. Hasil Fase Realisasi/ Konstruksi adalah perangkat yang telah dirancang dalam fase desain. Hasil Fase Pengujian, Evaluasi, dan Revisi ada dua, yakni: (a) hasil validasi ahli, dan (b) hasil uji coba lapangan. Hasil validasi yang dilakukan validator digunakan untuk merevisi perangkat pembelajaran yang sedang dikembangkan. Setelah perangkat pembelajaran dinyatakan valid maka perangkat diimplementasikan dalam pembelajaran di kelas dalam bentuk ujicoba lapangan (penelitian tindakan kelas). Hasil validasi 2 validator terhadap perangkat pembelajaran disajikan dalam Tabel 1.

Uji coba perangkat bertujuan untuk penyempurnaan perangkat pembelajaran. Uji coba pada penelitian ini hanya 2 siklus dengan setiap siklusnya hanya terdiri dari 4 pertemuan selama masing-masing 2 SKS. Untuk siklus 1: SAP pertemuan ke 3-4 membahas pengembangan penggalan silabus, pertemuan 5-6 membahas pengembangan skenario pembelajaran. Kreativitas pada siklus 1 adalah kreativitas mahasiswa secara berkelompok mengembangkan silabus dan skenario pembelajaran dengan memanfaatkan literatur beragam dan mengembangkan aktivitas belajar yang kreatif. Instrumen yang digunakan adalah lembar pengamatan kreativitas (mengembangkan perangkat pembelajaran) dan angket penilaian kreativitas. Mahasiswa secara berkelompok dikatakan kreatif apabila skor dalam kategori tinggi. Selain itu untuk melihat karakter cerdas, digunakan lembar angket penilaian diri karakter cerdas. Mahasiswa dikatakan memiliki karakter cerdas apabila skor dalam kategori tinggi. Siklus 1 diakhiri dengan pemberian tes kreativitas mahasiswa. Untuk siklus 2: SAP pertemuan 11-13 tentang praktek membelajarkan dan pertemuan 14 tentang menyelesaikan soal open-ended matematika kelas VII dan VIII. Instrumen yang digunakan adalah lembar penilaian pelaksanaan peer teaching (kreativitas dalam praktek membelajarkan materi matematika) dan lembar penilaian diri karakter cerdas (karakter cerdas). Siklus 2 diakhiri dengan tes 2. Uji coba perangkat ini dilaksanakan pada mahasiswa semester genap tahun akademik 2014/2015 rombel 4 sebanyak 45 mahasiswa. Data yang diperoleh dari ujicoba perangkat berupa keterlaksanaan proses pembelajaran (praktis), respon mahasiswa (praktis), dan data tes (efektif), aktivitas mahasiswa (efektif: kreativitas kelompok, penilaian karakter cerdas, dan pelaksanaan peer-teaching).

Untuk melihat kepraktisan perangkat, digunakan pengamatan terhadap keterlaksanaan pembelajaran dan respon mahasiswa. Hasil pengamatan terhadap keterlaksanaan pembelajaran yang diperoleh dari uji coba dapat dilihat pada Tabel 2.

Tabel 2. Hasil Pengamatan Keterlaksanaan Pembelajaran

\begin{tabular}{ccc}
\hline $\begin{array}{c}\text { Keterlaksanaan } \\
\text { Pembelajaran }\end{array}$ & Persentase & Kategori \\
\hline Siklus 1 & $91,6 \%$ & Baik \\
Siklus 2 & $89,5 \%$ & Baik \\
\hline Rata-rata & $90,6 \%$ & Baik \\
\hline
\end{tabular}


Berdasarkan Tabel 4.2 dan kriteria yang telah ditetapkan yaitu baik, kedua persentase tersebut mendapatkan ratarata hasil pengamatan yaitu $90,6 \%$ sehingga dapat ditarik kesimpulan kemampuan dosen dalam mengelola pembelajaran dalam kategori baik. Dengan demikian, perangkat pembelajaran dikatakan praktis digunakan. Untuk angket respon mahasiswa yang diisi oleh 45 mahasiswa setelah mengikuti pembelajaran dengan perangkat pembelajaran perangkat pembelajaran telaah kurikulum matematika 1 mengintegrasikan kreativitas dan karakter cerdas melalui pembelajaran kooperatif berbasis asesmen proyek. Rincian hasil angket respons mahasiswa tersebut dapat dilihat pada Tabel 3 .
Berdasarkan Tabel 3, dapat dianalisa bahwa respon positif mahasiswa terhadap semua aspek berada di atas 50\%. Artinya setiap aspek direspon positif oleh mahasiswa lebih dari $50 \%$. Artinya, perangkat pembelajaran praktis digunakan.

Untuk mengetahui kreativitas mahasiswa secara berkelompok pada siklus 1 menggunakan lembar pengamatan kreativitas dan angket penilaian kreativitas. Data kreativitas mahasiswa secara berkelompok berdasarkan lembar pengamatan dapat dilihat pada Tabel 4 .

Terlihat bahwa semua kelompok mahasiswa sudah menunjukkan kreativitas tinggi dalam mengembangkan perangkat pembelajaran matematika SMP kelas VII dan VIII. Meskipun masih ada 2 kelompok yang kategori tingginya masih di batas bawah kategori yai-

Tabel 3. Hasil Angket Respon Mahasiswa

\begin{tabular}{|c|c|c|}
\hline \multirow{2}{*}{ Aspek yang direspon } & \multicolumn{2}{|c|}{ Persentase Respon Mahasiswa } \\
\hline & Positif & Negatif \\
\hline $\begin{array}{l}\text { Perasaan senang terhadap komponen pembelajaran } \\
\text { Cara mengajar dosen } \\
\text { a. Suasana pembelajaran di kelas } \\
\text { b. Materi pembelajaran } \\
\text { c. Strategi pembelajaran }\end{array}$ & $\begin{array}{l}91,1 \% \\
88,9 \% \\
84,4 \% \\
93,3 \%\end{array}$ & $\begin{array}{c}8,9 \% \\
11,1 \% \\
15,6 \% \\
6,7 \%\end{array}$ \\
\hline $\begin{array}{l}\text { kebaruan komponen pembelajaran ini } \\
\text { a. Cara mengajar dosen } \\
\text { b. Suasana pembelajaran di kelas } \\
\text { c. Materi pembelajaran } \\
\text { d. Strategi pembelajaran }\end{array}$ & $\begin{array}{c}80 \% \\
86,7 \% \\
77,7 \% \\
95,5 \% \\
\end{array}$ & $\begin{array}{c}20 \% \\
13,3 \% \\
22,3 \% \\
4,5 \% \\
\end{array}$ \\
\hline $\begin{array}{l}\text { Adanya minat mengikuti pembelajaran mata kuliah lain dengan cara seperti dii- } \\
\text { kuti pada mata kuliah Telaah Kurikulum Matematika } 1\end{array}$ & $86,7 \%$ & $13,3 \%$ \\
\hline Pemahaman materi yang diajarkan & $86,7 \%$ & $13,3 \%$ \\
\hline Kreativitas dapat dimunculkan dalam pembelajaran & $84,4 \%$ & $15,6 \%$ \\
\hline karakter cerdas dapat dimunculkan dalam pembelajaran & $91,1 \%$ & $8,9 \%$ \\
\hline
\end{tabular}

Tabel 4. Hasil kreativitas mahasiswa berdasarkan lembar pengamatan

\begin{tabular}{|c|c|c|c|c|c|c|}
\hline \multirow{2}{*}{ Kelompok ke- } & \multicolumn{3}{|c|}{ Indikator } & \multirow{2}{*}{ Skor total } & \multirow{2}{*}{ persentase } & \multirow{2}{*}{ keterangan } \\
\hline & $\mathrm{K}_{1}$ & $\mathrm{~K}_{2}$ & $\mathrm{~K}_{2}$ & & & \\
\hline 1 & 2 & 2 & 2 & 6 & 100 & Tinggi \\
\hline 2 & 2 & 1 & 1 & 4 & 66,667 & Tinggi \\
\hline 3 & 1 & 2 & 2 & 5 & 83,333333 & Tinggi \\
\hline 4 & 2 & 1 & 2 & 5 & 83,333333 & Tinggi \\
\hline 5 & 2 & 1 & 2 & 5 & 83,333333 & Tinggi \\
\hline 6 & 1 & 2 & 2 & 5 & 66,667 & Tinggi \\
\hline 7 & 2 & 2 & 2 & 6 & 100 & Tinggi \\
\hline 8 & 2 & 1 & 1 & 4 & 83,333333 & Tinggi \\
\hline 9 & 1 & 2 & 2 & 5 & 83,333333 & Tinggi \\
\hline 10 & 1 & 2 & 2 & 5 & 83,333333 & Tinggi \\
\hline 11 & 2 & 1 & 2 & 5 & 83,333333 & Tinggi \\
\hline
\end{tabular}


tu 66,667 . Data kreativitas mahasiswa secara berkelompok berdasarkan angket penilaian kreativitas dapat dilihat pada Tabel 5 .

\begin{tabular}{ccc}
\multicolumn{3}{c}{ Tabel 5. Hasil Angket penilaian } \\
\hline kelompok ke & persentase & kategori \\
\hline 1 & 81,82 & tinggi \\
2 & 81,82 & Tinggi \\
3 & 86,36 & Tinggi \\
4 & 84,09 & Tinggi \\
5 & 84,09 & Tinggi \\
6 & 77,27 & Tinggi \\
7 & 88,64 & Tinggi \\
8 & 84,09 & Tinggi \\
9 & 84,09 & Tinggi \\
10 & 88,64 & Tinggi \\
11 & 88,64 & Tinggi \\
\hline
\end{tabular}

Terlihat bahwa semua kelompok mahasiswa sudah menunjukkan kreativitas tinggi dalam mengembangkan perangkat pembelajaran matematika SMP kelas VII dan VIII. Pada siklus 1 , berdasarkan lembar pengamatan kreativitas dan angket penilaian kreativitas terlihat bahwa kelompok mahasiswa menunjukkan karakteristik kreatif tinggi.

Persentase karakter cerdas seluruh mahasiswa pada siklus 1 adalah $72,2 \%$ dengan kategori sedang. Terlihat bahwa pada siklus 1 masih ada indikator karakter cerdas yang dalam kategori sedang. Persentase setiap indikator dari karakter cerdas setiap mahasiswa ditampilkan pada Tabel 6.

Tabel 6. Hasil karakter cerdas mahasiswa

\begin{tabular}{lcc}
\hline \multicolumn{1}{c}{ Indikator } & \multicolumn{2}{c}{ Siklus 1 } \\
\cline { 2 - 3 } & $\begin{array}{c}\text { Persen- } \\
\text { tase }\end{array}$ & kategori \\
\hline $\begin{array}{l}\text { berpikir logis sesuai dengan } \\
\text { konsep ilmu pengetahuan, } \\
\text { teknologi, seni, dan/atau } \\
\text { olahraga }\end{array}$ & 75,83 & Tinggi \\
$\begin{array}{l}\text { menemukan kebenaran se- } \\
\text { cara logis dan metodologis } \\
\text { memecahkan masalah }\end{array}$ & 69,16 & Sedang \\
$\begin{array}{l}\text { secara tepat dan akurat ber- } \\
\text { dasarkan data empiris } \\
\text { kreatif dalam mengem- }\end{array}$ & 67,5 & Sedang \\
bangkan model atau cara- \\
$\begin{array}{l}\text { cara yang baru } \\
\text { menemukan solusi secara } \\
\text { cepat berdasarkan pemiki- } \\
\text { ran yang logis }\end{array}$ & 65,83 & Sedang \\
\hline
\end{tabular}

Untuk mengetahui kreativitas mahasiswa setelah dilakukan pembelajaran menggunakan perangkat pembelajaran telaah kurikulum matematika 1 mengintegrasikan kreativitas dan karakter cerdas melalui pembelajaran kooperatif berbasis asesmen proyek dilakukan tes 1 . Tes 1 ini berkaitan dengan menyelesaikan soal open-ended matematika SMP kelas VII dan VIII. Hasil tes kreativitas ditunjukkan pada Tabel 7.

Tabel 7. Hasil tes kreativitas siklus 1

\begin{tabular}{cc}
\hline Uraian & Nilai \\
\hline Nilai terendah & 66 \\
Nilai tertinggi & 89 \\
\hline Rata-rata & 84 \\
\hline
\end{tabular}

Selain itu, banyaknya mahasiswa dalam kategori kreatif berdasarkan tes ada 40 mahasiswa $(88,88 \%)$ dan 5 mahasiswa dalam kategori kurang kreatif $(11,12 \%)$. Lebih dari $75 \%$ mahasiswa menunjukkan kreatif.

Kreativitas mahasiswa secara berkelompok dalam mengembangkan perangkat pembelajaran berdasarkan lembar pengamatan dan angket dalam kategori baik. Berdasarkan tes, mahasiswa juna menunjukkan kreatif. Namun karakter cerdas mahasiswa masih kategori sedang dan per indikator, masih ada karakter cerdas yang sedang. Oleh karena itu perlu ditindak lanjuti dengan siklus 2 .

Pada siklus 2, untuk melihat kreativitas mahasiswa dengan menggunakan lembar pengamatan pelaksanaan peer teaching. Pengamatan dilaksanakan pada saat setiap kelompok mahasiswa mempraktekkan membelajarkan materi matematika kelas VII atau VIII. Pada tabel berikut ini dicantumkan nilai rata-rata, tertinggi, dan terendah.

Tabel 8. Rangkuman Nilai Peer teaching

\begin{tabular}{cc}
\hline \hline Uraian & Nilai \\
\hline Nilai Rata-rata & 86 \\
Nilai tertinggi & 94 \\
Nilai terendah & 76 \\
\hline \hline
\end{tabular}

Mahasiswa secara berkelompok telah menunjukkan kreativitas praktek membelajarkan yang tinggi.

Persentase karakter cerdas seluruh ma- 
hasiswa pada siklus 2 adalah $85,3 \%$ dengan kategori tinggi. Persentase setiap indikator dari karakter cerdas setiap mahasiswa ditampilkan pada Tabel 9.

Tabel 9. Hasil karakter cerdas tiap indikator

\begin{tabular}{lcc}
\hline \multirow{2}{*}{ Indikator } & \multicolumn{2}{c}{ Siklus 2 } \\
\cline { 2 - 3 } & Persentase & Kategori \\
\hline $\begin{array}{l}\text { berpikir logis sesuai dengan } \\
\text { konsep ilmu pengetahuan, } \\
\text { teknologi, seni, dan/atau } \\
\text { olahraga }\end{array}$ & 79,4 & Tinggi \\
$\begin{array}{l}\text { menemukan kebenaran se- } \\
\text { cara logis dan metodologis }\end{array}$ & 84,4 & Tinggi \\
$\begin{array}{l}\text { memecahkan masalah secara } \\
\text { tepat dan akurat berdasarkan } \\
\text { data empiris }\end{array}$ & 85 & Tinggi \\
$\begin{array}{l}\text { kreatif dalam mengembang- } \\
\text { kan model atau cara-cara } \\
\text { yang baru } \\
\text { menemukan solusi secara } \\
\text { cepat berdasarkan pemikiran } \\
\text { yang logis }\end{array}$ & 87,7 & Tinggi \\
\hline
\end{tabular}

Pada siklus kedua, semua indikator karakter cerdas dalam kategori tinggi. Berdasarkan perhitungan karakter cerdas secara keseluruhan maupun per indikator berada pada kategori tinggi.

Untuk mengetahui kreativitas mahasiswa setelah dilakukan pembelajaran menggunakan perangkat pembelajaran telaah kurikulum matematika 1 mengintegrasikan kreativitas dan karakter cerdas melalui pembelajaran kooperatif berbasis asesmen proyek dilakukan tes 2 . Tes 2 ini berkaitan dengan pemahaman dan kreativitas mahasiswa tentang materi perkuliahan. Hasil tes kreativitas ditunjukkan pada Tabel 10.

Tabel 10. Hasil tes kreativitas siklus 2

\begin{tabular}{cc}
\hline Uraian & Nilai \\
\hline Nilai terendah & 75 \\
Nilai tertinggi & 99 \\
\hline Rata-rata & 87 \\
\hline
\end{tabular}

Untuk mengetahui kreativitas mahasiswa setelah dilakukan pembelajaran menggunakan perangkat pembelajaran telaah kurikulum matematika 1 mengintegrasikan kreativitas dan karakter cerdas melalui pembelajaran kooperatif berbasis asesmen proyek dilakukan tes 2 . Tes 2 ini berkaitan dengan pemahaman dan kreativitas mahasiswa tentang materi perkuliahan. Hasil tes kreativitas ditun- jukkan pada Tabel 11.

Tabel 11. Hasil tes kreativitas siklus 2

\begin{tabular}{cc}
\hline Uraian & Nilai \\
\hline Nilai terendah & 75 \\
Nilai tertinggi & 99 \\
\hline Rata-rata & 87 \\
\hline
\end{tabular}

Selain itu, banyaknya mahasiswa dalam kategori kreatif berdasarkan tes ada 45 mahasiswa (100\%). Lebih dari 75\% mahasiswa menunjukkan kreatif. Peningkatan kreatif dari siklus 1 ke siklus $2(88,88 \%$ ke $100 \%$ adalah $11,11 \%)$. Lebih dari $5 \%$ peningkatan kreativitas mahasiswa berdasar tes 2.

Kreativitas mahasiswa secara berkelompok dalam praktek membelajarkan dalam kategori baik. Berdasarkan tes, mahasiswa juga menunjukkan kreatif. Karakter cerdas mahasiswa tinggi. Oleh karena itu pembelajaran berhenti hanya sampai siklus 2. Dengan demikian perangkat pembelajaran yang dikembangkan efektif untuk digunakan.

\section{PEMBAHASAN}

Pengembangan perangkat pembelajaran pada penelitian ini meliputi mengembangkan (1) penggalan silabus, (2) satuan acara perkuliahan, (3) kontrak perkuliahan, (4) instrumen penilaian kreativitas, (5) angket penilaian diri karakter cerdas, (6) instrumen penilaian pelaksanaan peer teaching, (7) lembar pengamatan kreativitas mahasiswa, (8) asesmen proyek (9) Tes matematika yang sesuai dengan dengan pembelajaran kooperatif dengan integrasi kreativitas dan karakter cerdas pada telaah kurikulum matematika 1 yang mengintegrasikan kreativitas dan karakter cerdas melalui pembelajaran kooperatif berbasis asesmen proyek. Menurut validator ahli, perangkat yang dikembangkan sudah valid sehingga dapat diimplementasikan dalam pembelajaran di kelas.

Perangkat pembelajaran yang dikembangkan dikatakan praktis jika pengamatan terhadap keterlaksanaan dan respon mahasiswa. Berdasarkan data keterlaksanaan pembe- 
lajaran di siklus 1 dan 2 diperoleh fakta bahwa perangkat pembelajaran praktis digunakan.

Keefektifan perangkat pembelajaran dilihat menggunakan 2 tolak ukur yaitu hasil belajar (tes mengukur kreativitas mahasiswa) dan aktivitas mahasiswa (menggunakan lembar pengamatan kreativitas, angket penilaian kreativitas, lembar pengamatan pelaksanaan peer teaching, angket penilaian diri karakter cerdas). Pada siklus 1, kreativitas diukur menggunakan digunakan instrumen lembar pengamatan kreativitas, angket penilaian kreativitas, angket penilaian diri karakter cerdas dan tes 1. Berdasarkan lembar pengamatan kreativitas, angket penilaian kreativitas dan tes 1 diperoleh fakta bahwa mahasiswa kreatif. Namun berdasarkan angket penilaian diri karakter cerdas, mahasiswa masih tergolong karakter cerdasnya sedang. Hal ini didukung 3 indikator dari 5 indikator karakter cerdas yaitu menemukan kebenaran secara logis dan metodologis, memecahkan masalah secara tepat dan akurat berdasarkan data empiris, kreatif dalam mengembangkan model atau cara-cara yang baru juga masih dalam kategori sedang. Ini menunjukkan nilai karakter konservasi yaitu cerdas masih belum maksimal. Padahal dalam bidang kajian matematika, dibutuhkan karakter cerdas sehingga mahasiswaaa dapat menyelesaikan masalah matematika dan nantinya dapat menyelesaikan masalah kehidupan sehari-hari yang membutuhkan pemikiran yang logis dan algoritma yang benar.

Selanjutkan penelitian berlanjut dengan siklus 2. Pada siklus 2 ini juga dilihat kreativitas mahasiswa dalam kegiatan praktek pembelajaran dan karakter cerdas. Pada siklus 2 digunakan lembar pengamatan pelaksanaan peer teaching, angket penilaian diri karakter cerdas, dan tes 2. Terlihat bahwa kreativitas mahasiswa saat praktek membelajarkan dalam kategori tinggi dan karakter cerdasnya dalam kategori tinggi. Pada siklus 2 digunakan lembar pengamatan pelaksanaan peer teaching, angket penilaian diri karakter cerdas, dan tes 2 . Oleh karena itu, pembelajaran berhenti pada siklus 2. Saat praktek membelajarkan, mahasiswa mengembangkan dan menggunakan alat peraga matematika, menggunakan video pembelajaran materi tertentu yang diperoleh dari youtube, dan sumber belajar selain buku siswa dan buku bse matematika (sumber literatur diperoleh dari internet). Hal ini menunjukkan kreativitas mahasiswa. Pada siklus 1, kreativitas mahasiswa dimunculkan dalam bentuk aktivitas pengembangan perangkat pembelajaran (penggalan silabus, skenario pembelajaran, bahan ajar) dengan memanfaatkan sumbersumber dari internet. Kreativitas mahasiswa ini selalu digali dalam bentuk aktivitas. Hal ini senada dengan penelitian Kurtzberg \& Reale, 1999; Antonietti, 2000; Komarik \& Brutenicova, 2003; Garaigordobil, 2006 (dalam Wu et all,2013) oleh yang menyatakan bahwa kreativitas digali melalui sejumlah kegiatan. Kreativitas mahasiswa dibiasakan dalam kegiatan secara berkelompok. Setiap kelompok terdiri dari 4 mahasiswa. Pada siklus 1 setiap kelompok mengembangkan perangkat pembelajaran matematika kelas VII dan VIII sedangkan pada siklus 2 setiap kelompok mempraktekkan pembelajaran matematika kelas VII dan VIII. Hal ini meningkatkan kreativitas mahasiswa. Kenyataan ini didukung pernyataan Paulus (dalam Kim, 2012) yaitu interaksi dalam kelompok merupakan sumber ide-ide kreatif dan inovasi.

Kreativitas mahasiswa juga terlihat saat mengerjakan tes, misalnya soal no 2 tes siklus 1. Mahasiswa mampu menunjukkan keberagaman kemungkinan jawaban lalu memutuskan mana jawaban yang dipilihnya dengan argumentasi yang kuat. Berikut ini salah satu soal dan hasil pekerjaan mahasiswa dengan soal dapat dilihat pada gambar 2 .

Sebelum praktek membelajarkan, setiap kelompok mahasiswa telah berkonsultasi dengan dosen pengampu sehingga materi matematika yang akan disampaikan tepat dan caranya juga tepat. Bantuan dari dosen pengampu ini merupakan scaffolding dalam teori belajar Vigotsky. Menurut Vigotsky, seseorang yang belajar dan menyelesaikan masalah dengan bekerja sama dengan orang lain maupun orang dewasa akan menunjukkan kemampuan yang lebih daripada seseorang yang belajar secara mandiri. Simons dan Klein (dalam Choo, 2011) menguji pengaruh scaffolding dan prestasi belajar siswa dalam setting PBL dimana subjek yang diteliti dikenai scaffolding yang berbeda. Hasil dari penelitian ini 

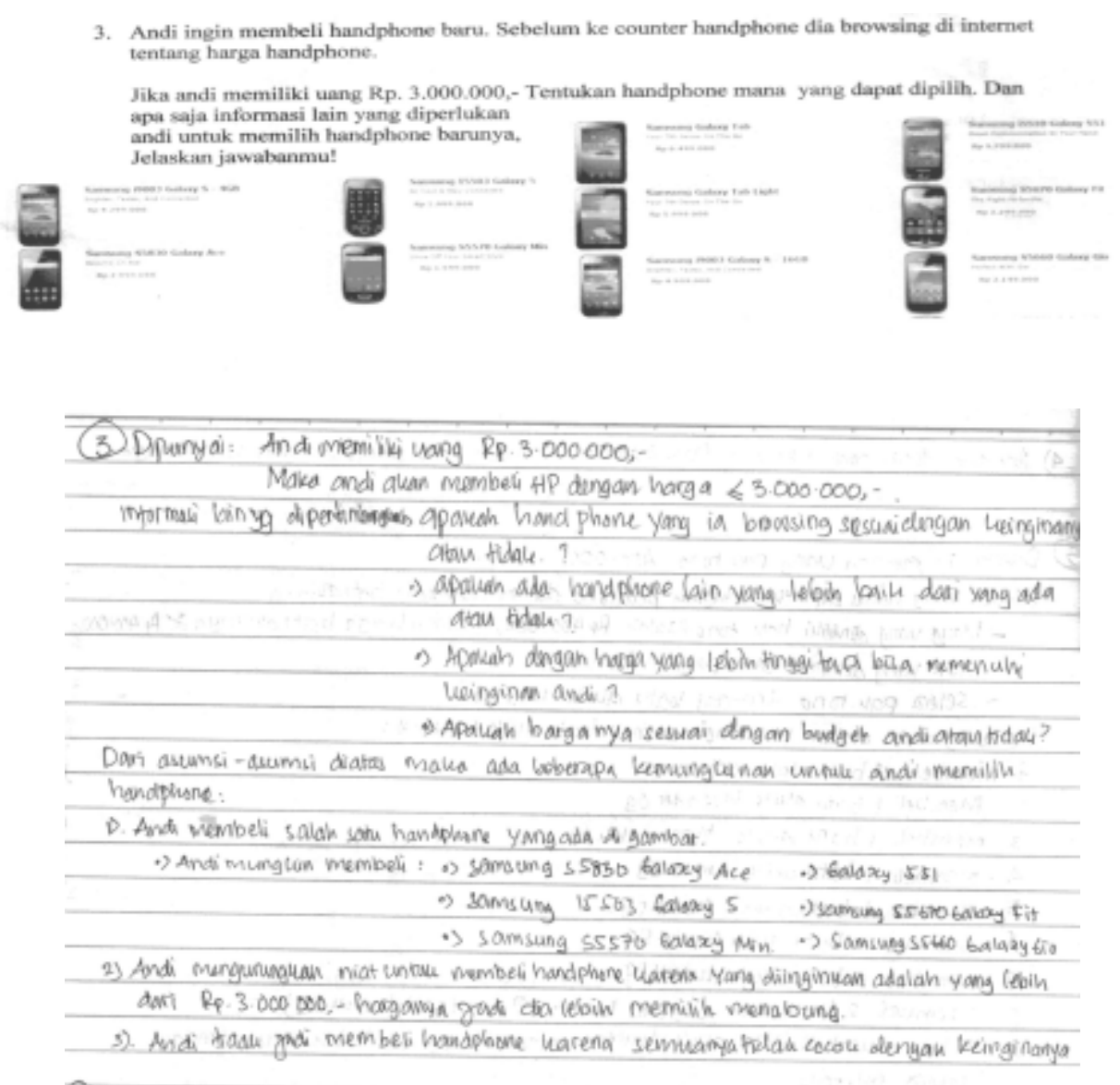

\section{Gambar 2. Soal dan Hasil pekerjaan salah satu mahasiswa}

adalah seseorang yang diberi bantuan belajar memperoleh hasil posttest yang lebih baik daripada seseorang yang tidak diberi bantuan belajar Diaz dkk (dalam McMahon, 2000) menyatakan bahwa dosen yang memberikan scaffolding kepada mahasiswanya akan menghindarkan mahasiswa dari frustasi dan mendorong mahasiswa belajar secara bebas. Hal ini senada dengan pernyataan Clay dan Cazden (1990) yang menyatakan bahwa dalam ZPD, seseorang tidak pasif menerima pengetahuan dari orang dewasa namun ada kerjasama antara seseorang yang belajar dan seseorang dewasa yang membantu belajar dalam melakukan aktivitas problem solving.

\section{PENUTUP}

\section{Simpulan}

Pengembangan perangkat pembelajaran telaah kurikulum matematika 1 men- gintegrasikan kreativitas dan karakter cerdas melalui pembelajaran kooperatif berbasis asesmen proyek mengacu pada teori pengembangan yang dikemukakan oleh Plomp dengan fase-fase (1) investigasi awal, (2) Design, (3) Realisasi, dan (4) Tes, evaluasi, dan revisi. Perangkat yang dikembangkan meliputi penggalan silabus, (2) satuan acara perkuliahan, (3) kontrak perkuliahan, (4) instrumen penilaian kreativitas, (5) angket penilaian diri karakter cerdas, (6) instrumen penilaian pelaksanaan peer teaching, (7) lembar pengamatan kreativitas mahasiswa, (8) asesmen proyek (9) Tes matematika yang sesuai dengan dengan pembelajaran kooperatif dengan integrasi kreativitas dan karakter cerdas pada telaah kurikulum matematika 1 yang mengintegrasikan kreativitas dan karakter cerdas melalui pembelajaran kooperatif berbasis asesmen proyek.

Hasil pengembangan Perangkat Pembelajaran Telaah Kurikulum Matematika 1 
Mengintegrasikan Kreativitas dan Karakter Cerdas Melalui Pembelajaran Kooperatif Berbasis Asesmen Proyek diperoleh perangkat yang valid. Implementasi pengembangan Perangkat Pembelajaran Telaah Kurikulum Matematika 1 Mengintegrasikan Kreativitas dan Karakter Cerdas Melalui Pembelajaran Kooperatif Berbasis Asesmen Proyek menunjukkan praktis dan efektif.

\section{Saran}

Berdasarkan penelitian yang dilakukan, disarankan beberapa hal sebagai berikut. Perangkat pembelajaran yang dihasilkan ini baru sampai pada tahap pengembangan, belum diimplementasikan. Untuk mengetahui keefektifannya, disarankan untuk mengimplementasikan perangkat pembelajaran ini pada ruang lingkup yang lebih luas. Penelitian ini menghasilkan perangkat pembelajaran yang valid, efektif, dan praktis maka perangkat pembelajaran tersebut dapat digunakan dan dikembangkan dalam perkulaiahn Telaah Kurikulum Matematika 1 di tahun akademik selanjutnya.

\section{DAFTAR PUSTAKA}

Choo, S. S., Rotgans, J. I., Yew, E. H., \& Schmidt, H. G. (2011). Effect of worksheet scaffolds on student learning in problem-based learning. Advances in health sciences education, 16(4), 517-528.

Clay, M., \& Cazden, C. (1990). In L.C. Moll (Ed.), Vygotsky and education: Instructional implications A Vygotskian interpretation of Reading Recovery and applications of sociohistorical psychology. (pp. 206-222). Cambridge: Cambridge University Press.

Department Education Republic of South Africa. Tan- pa tahun. National Curriculum Statement Assessment Guidelines for General Education and Training (Intermediate and Senior Phases) Mathematics. Online. (http://www.education.gov.za/ LinkClick.aspx?fileticket=t\%2Bo3xrnWEZ4\%3D \&tabid=267\&mid, diakses 11 Januari 2015)

Depdikbud. (2014). Peraturan Menteri Pendidikan dan Kebudayaan Republik Indonesia Nomor 58 Tahun 2014 tentang Kurikulum 2013 Sekolah Menengah Pertama/ Madrasah Tsanawiyah. Jakarta: Depdikbud

Jbeili, I. (2012). The Effect of Cooperative Learning with Metacognitive Scaffolding on Mathematics Conceptual Understanding and Procedural Fluency. International Journal for Research in Education (IJRE), 32. (online).(http://www.cedu.uaeu.ac.ae/ journal/issue32/ch9_32en.pdf, diakses 29 April 2015)

Kim, S. H., \& Song, K. S. (2013). The effects of thinking style based cooperative learning on group creativity. Creative Education, 3(08), 20-24.

Li, M.P., Lam, B.H. (2013). Cooperative Learning. The Hong Kong Institute of Education.

Masrukan. (2014). Asesmen Otentik Pembelajaran Matematika: Mencakup asesmen afektif dan karakter. Semarang: Unnes

McMahon, B. E. (2000). Scaffolding: A suitable teaching characteristic in one-to-one

teaching in Maths Recovery. In Bana, Jack and Chapman, Anne, Eds. Proceedings Mathematics Education Beyond 2000 , pages 417-423, Fremantle, Western Australia.

Plomp, Tj. (1997). Educational Design: Introduction. From Tjeerd Plomp (eds). Educational \& Training System Design: Introduction. Design of Education and Training (in Dutch). Utrecht (the Netherlands): Lemma. Netherland. Faculty

Unnes. (2012). Buku Panduan Implementasi Kurikulum 2012 Unnes. Semarang

Wu, C. H., Hwang, G. J., Kuo, F. R., \& Huang, I. (2013). A mindtool-based collaborative learning approach to enhancing students' innovative performance in management courses. Australasian Journal of Educational Technology, 29(1). 